
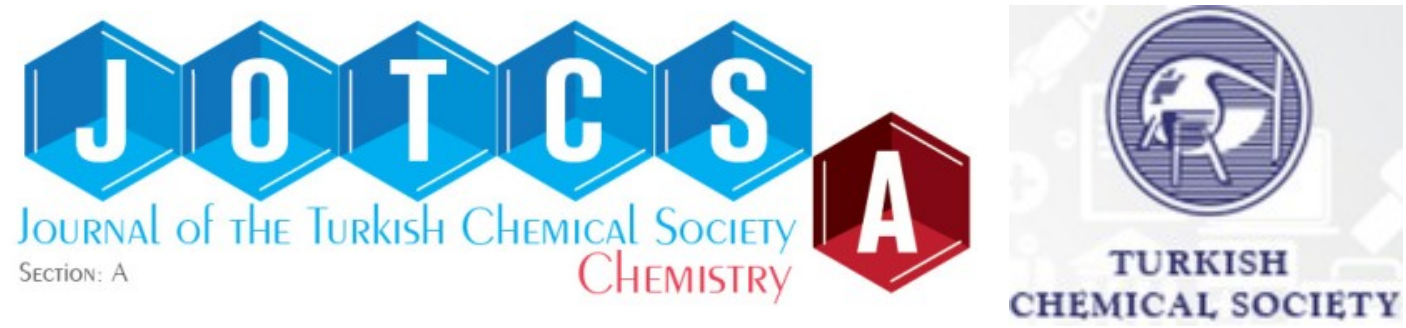

\title{
Exposure Analysis at the Territory of Nevşehir (Cappadocia) due to Additive Gamma-rays in Air, Turkey
}

\author{
Muttalip Ergun TURGAY ${ }^{1}$, (iD) Merve CİCEKFIDAN², (iD, Nursel SEZGİN ${ }^{3}$ \\ ${ }^{1}$ Yalova University, Yalova, Turkey \\ ${ }^{2}$ Yildiz Technical University, İstanbul, Turkey \\ ${ }^{3}$ Van Yuzunci Yil University, Van, Turkey
}

\begin{abstract}
Radioactivity measurements for water, soil, and air have been completed in national and international regions. The radioactivity process is randomized and occurs naturally by primordial nuclides. Another case is hand-made reactions which realized by artificial reactions. The high rate of the total dose of radiation, whichever is exposed to humans, originates as Natural Radioactivity. In this case, environmental radioactivity measurements are important to investigate the background radiation level, especially for primordial radioactive sources. This radiation which measured outdoor gamma dose includes both cosmic rays and terrestrial elements. Terrestrial radiation can be measured via gamma-ray spectroscopy separately. By the way, cosmic effects would be calculated by subtracting terrestrial from measured outdoor gamma dose. Scientific Committee (UNSCEAR, 2000) declares the annual dose for humans as $2.4 \mathrm{mSv}$. The radionuclides present in soil samples (terrestrial components) are considered responsible for a portion of this amount (1). Rest amounts are originated water (2) and air, too.
\end{abstract}

Submitted: March 04, 2021. Accepted: February 08, 2022.

Cite this: Turgay M, Cicekfidan M, Sezgin N. Exposure Analysis at the Territory of Nevşehir (Cappadocia) due to Additive Gamma-rays in Air, Turkey. JOTCSA. 2022;9(2):321-30.

DOI: https://doi.org/10.18596/jotcsa.891062.

*Corresponding author. E-mail: eturgay20@hotmail.com.

\section{INTRODUCTION}

\section{Literature Survey}

Over the past two decades, a few results about radioactivity levels have been published in some papers related to gamma dose rates in the air for Turkish provinces (3-14). There is no study specifically for the Nevşehir region in the literature. Therefore, the purpose of our effort is to measure dose rates in the air from different locations throughout the city and, in this way, to determine the cancer risk. The human population in this city is up to one million, and this study will be the baseline for subsequent studies about environmental radioactivity measurements. By the way, there are also stated worldwide studies in the literature. For example, Licínio MV and friends have evaluated in 2013 for Brazil (15). Another study by GhiassiNejad and Mortavazi in 2002 indicates the absorbed dose rates in air (ADRA) values concerning the Ramsar region of Persia. They studied the effects of radiation on human life. The annual dose was also calculated (260 mSv), and found higher than the stipulated annual limit of $20 \mathrm{mSv}$ in North Persia. Cytogenetic studies show no significant differences between people in the high background compared to people in normal background areas (16). The third study with Arnedo MA and coworkers reported the natural radioactivity of soils in the eastern Canary islands (17).

\section{MATERIAL AND METHODS}

\section{Airborne Radiation and its Reading}

Airborne radioactivity could be assigned on the spectrum on the spectrum peaks' one by one, showing the related nuclides. Radionuclides will very rapidly appear in ground-level air, and air samples can give the first indication on the nature of the contamination. Radioactive elements in the air could reduce due to human inhalation. Gamma dose rates were measured using a counter (reader: Eberline, ESP-2) as a mobile device and connected to the detector as a SPA- 6 model plastic scintillator. The instrument was kept up to $1 \mathrm{~m}$ from the soil surface, and at the sampling point, the 
measurement duration was 60 seconds. Then the average dose rates were recorded. The main instrument is ESP-2.

The detector is connected through a coaxial type MHV series. The readout function has been shown in $2 \times 16$ alphanumeric display-LCD. This ratemeter is operated by the CPU@ Intel_80C31 processor family and has external RAM- $8 \mathrm{~KB}$ and EPROM is $16 \mathrm{~KB}$. The scintillation detector body, SPA-6, which is connected to the counter (ESP-2), was selected to optimize its output for the radiation of interest. It provides the pulse signal to the electronics in order to the readout. On the detector side, the pulse rate is proportional to the intensity of radiation. The high voltage supply offers the required bias potential to the detector. This voltage is keyboard adjustable, and it controls the correct operating voltages for different detectors. The low voltage supply regulates the operating voltage for the ESP-2 electronics, as shown in Figure 1 (18). The amplifier is linear and amplifies the probe's signal to a functional level at the amplifier output. The discriminator provides a signal on its output only if the amplifier's signal exceeds the adjustable threshold. It provides rejecting for noise and unwanted signal.

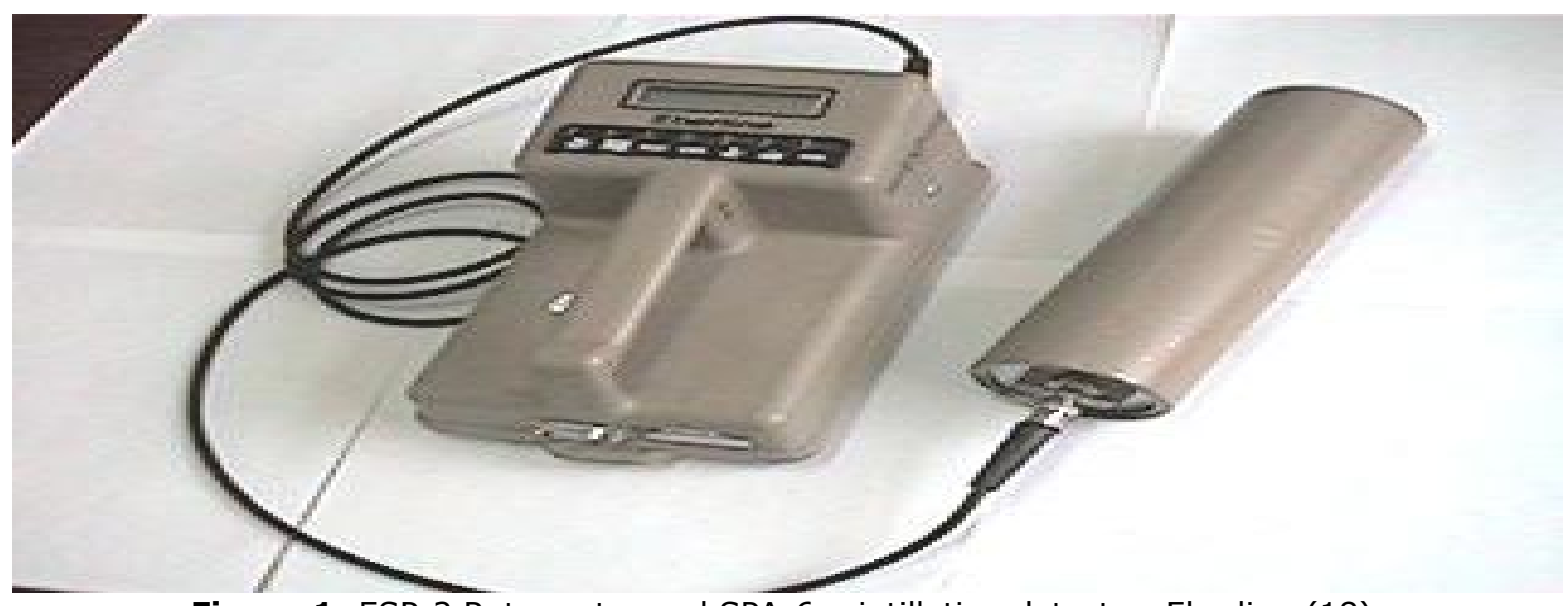

Figure 1: ESP-2 Rate meter and SPA-6 scintillation detector, Eberline (18).

\section{Measuring Area}

Cappadocia (Nevşehir), one of Turkey's central regions, is a neighbor to the capital city of Ankara. Its coordinates are between 38.154 to $38.9428 \mathrm{~N}$ as latitude and 34.1747 to $34.9038 \mathrm{E}$ as longitude. The highest point is Ercas (1982 $\mathrm{m}$ ), and other points are Hodul (1949 $\mathrm{m}$ ) and Kızıldağ (1768 m). The province of Nevşehir is surrounded by $18 \%$ mountain, $25 \%$ plain, $57 \%$ plateau, and hillside. The province was settled on the west side of a large plateau formed by ash and volcanoes, in the Anatolian span. River Kızılırmak is separated into two all city of Nevşehir. The climate is terrestrial, like cold-dry winters and hot, dry summers. The region's area is $5467 \mathrm{~km}^{2}$ (19), and its population is 0.16 million (19). Nevşehir's map is shown in Figure 2 .

\section{RESULTS}

Outdoor Dose Rates as Additive (Terrestrial and Cosmic Ray Effects)

Absorbed gamma doses are originated from terrestrial and cosmic rays together. In order to obtain the absorbed gamma dose rates in the air, the instrument was kept about 1 meter upperside from ground level. It is important to know how much exposure in the air to human gonads is about this level. The human gonad is the most vulnerable organ to radiation damage. Annual doses in the air were also calculated by using the gamma dose rates. In this case, measurements were perfected for a total of 45 different points. Dose rate map was shown in Figure 3. 


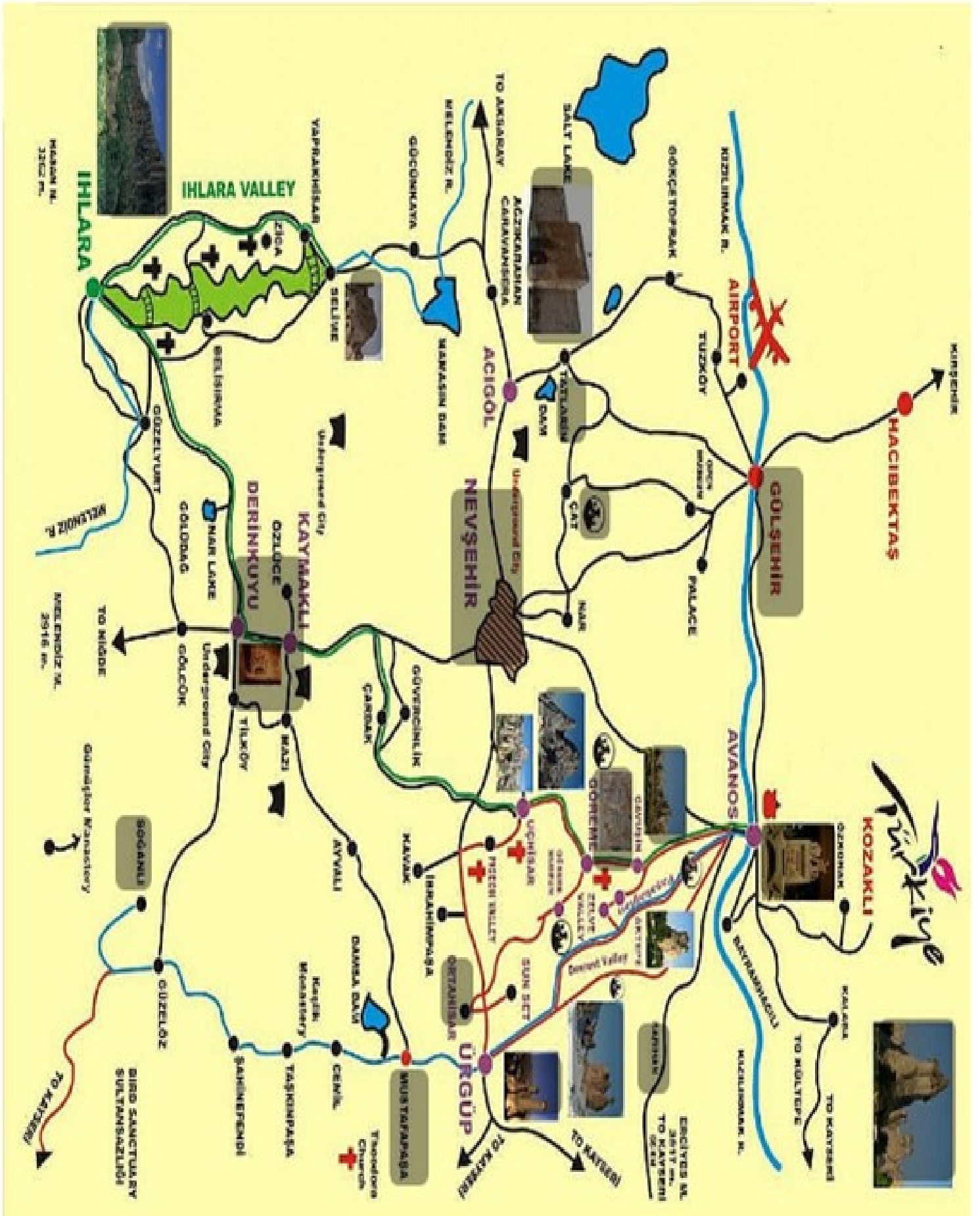

Figure 2: Regional roadMap of Nevşehir, Turkey (20). 
Table 1: Dose rates, coordinates, and altitudes of Cappadocia's sampling points.

\begin{tabular}{|c|c|c|c|c|}
\hline Name of measuring district & $\begin{array}{r}\text { Dose Rate } \\
{\left[\mathrm{nGy} \mathrm{h}^{-1}\right]}\end{array}$ & $\begin{array}{c}\text { Latitude } \\
\text { (pointed) }\end{array}$ & $\begin{array}{r}\text { Longitude } \\
\text { (pointed) }\end{array}$ & $\begin{array}{l}\text { Altitude } \\
\text { (meter) }\end{array}$ \\
\hline Ihlara Valley & 192.06 & 38.1540 & 34.1747 & 1180 \\
\hline Derinkuyu1 & 157.14 & 38.3735 & 34.7354 & 1350 \\
\hline Derinkuyu2 & 165.87 & 38.3737 & 34.7344 & 1350 \\
\hline Uçhisar1 (center) & 200.79 & 38.6205 & 34.8049 & 1340 \\
\hline Uçhisar2 (center) & 192.06 & 38.6314 & 34.7972 & 1310 \\
\hline Uçhisar3 (center) & 165.87 & 38.6291 & 34.8070 & 1300 \\
\hline Paşabağları (Ürgüp) & 192.06 & 38.6773 & 34.8560 & 1020 \\
\hline Çavuşin (Avanos) & 183.33 & 38.6767 & 34.8575 & 1050 \\
\hline Göreme1 (center) & 130.95 & 38.7274 & 34.8214 & 940 \\
\hline Göreme (Open air museum1) & 165.87 & 38.6386 & 34.8451 & 1140 \\
\hline Göreme (Open air museum2) & 192.06 & 38.6384 & 34.8453 & 1140 \\
\hline Göreme (Open air museum3) & 183.33 & 38.6385 & 34.8455 & 1150 \\
\hline Göreme (Open air museum4) & 200.79 & 38.6382 & 34.8457 & 1140 \\
\hline Göreme (Open air museum5) & 192.06 & 38.6384 & 34.8458 & 1150 \\
\hline Göreme (Open air museum6) & 226.98 & 38.6389 & 34.8461 & 1140 \\
\hline Göreme (Open air museum7) & 139.68 & 38.6432 & 34.8366 & 1130 \\
\hline Göreme (Open air museum8) & 157.14 & 38.6403 & 34.8450 & 1120 \\
\hline Göreme (Open air museum9) & 192.06 & 38.6411 & 34.8440 & 1100 \\
\hline Göreme (Open air museum10) & 174.60 & 38.6397 & 34.8448 & 1130 \\
\hline Cappadocia (central1) & 174.60 & 38.6288 & 34.7158 & 1190 \\
\hline Cappadocia (central2) & 183.33 & 38.6289 & 34.7228 & 1190 \\
\hline Cappadocia (central3) & 392.85 & 38.6282 & 34.7240 & 1200 \\
\hline Cappadocia (central4) & 157.14 & 38.6281 & 34.7245 & 1200 \\
\hline Cappadocia (central5) & 192.06 & 38.6277 & 34.7256 & 1210 \\
\hline Cappadocia (central6) & 200.79 & 38.6280 & 34.7264 & 1210 \\
\hline Cappadocia (central7) & 174.60 & 38.6282 & 34.7268 & 1210 \\
\hline Cappadocia (central8) & 157.14 & 38.6278 & 34.7271 & 1220 \\
\hline Cappadocia (central9) & 139.68 & 38.6279 & 34.7275 & 1220 \\
\hline Cappadocia (central10) & 200.79 & 38.6278 & 34.7281 & 1230 \\
\hline Cappadocia (central11) & 139.68 & 38.6274 & 34.7281 & 1230 \\
\hline Cappadocia (central12) & 158.89 & 38.6279 & 34.7273 & 1230 \\
\hline Cappadocia (central13) & 185.08 & 38.6275 & 34.7264 & 1220 \\
\hline Cappadocia (central14) & 107.38 & 38.6265 & 34.7250 & 1210 \\
\hline Cappadocia (central15) & 139.68 & 38.6276 & 34.7241 & 1210 \\
\hline Cappadocia (central16) & 200.79 & 38.6278 & 34.7223 & 1190 \\
\hline Cappadocia (central17) & 157.14 & 38.6271 & 34.7203 & 1190 \\
\hline Avanos1 & 192.06 & 38.6876 & 34.8329 & 950 \\
\hline Avanos2 & 148.41 & 38.7017 & 34.8417 & 950 \\
\hline Avanos3 & 134.44 & 38.7013 & 34.8421 & 930 \\
\hline Avanos4 & 192.06 & 38.7027 & 34.8403 & 950 \\
\hline Ürgüp (Üç Güzeller) & 165.87 & 38.6411 & 34.8440 & 1170 \\
\hline Ürgüp (Turasan1) & 157.14 & 38.6329 & 34.9038 & 1130 \\
\hline Ürgüp (Turasan2) & 183.33 & 38.6373 & 34.8446 & 1130 \\
\hline Ortahisar (Derbent) & 192.06 & 38.6725 & 34.8855 & 1070 \\
\hline Nevşehir (45) & $\begin{array}{l}209.52 \\
178.69 \\
n G y / h\end{array}$ & $\begin{array}{c}38.9428 \\
\text { Average } \\
\text { value of } \\
\text { ADRA }\end{array}$ & 34.5625 & 1300 \\
\hline
\end{tabular}




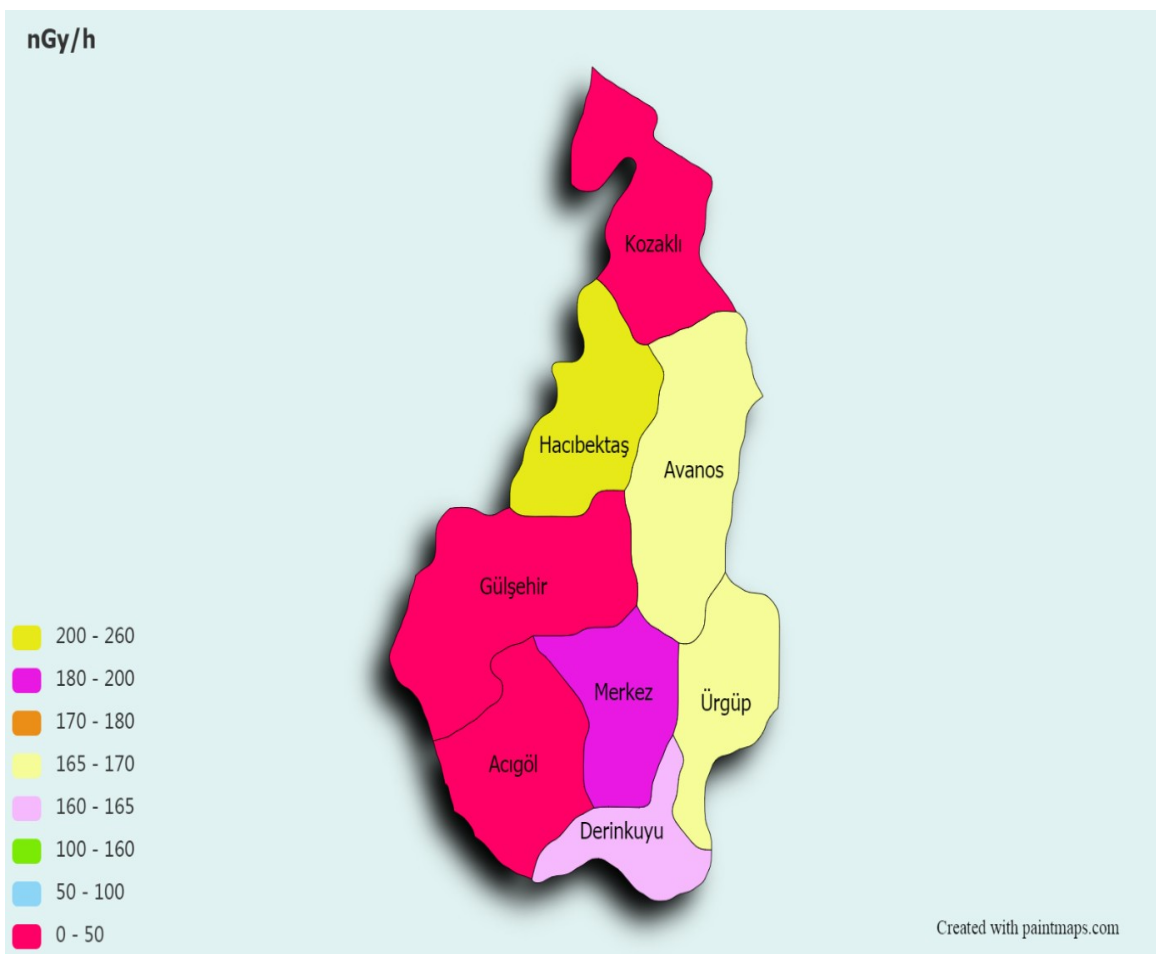

Figure 3: Outdoor Gamma Dose Rate map for Cappadocia district (Nevşehir)(21).

\section{Calculations}

Annual Effective Dose Equivalent (AEDE) and Excess Lifetime Cancer Risk (ELCR) were calculated in the literature using ADRA (1):

$$
\begin{aligned}
& A E D E=A D R A * D C F * O F * T \\
& E L C R=A E D E * D L * R F
\end{aligned}
$$

DCF signs the dose conversion factor $\left(0.7 \mathrm{~Sv} \mathrm{~Gy}^{-1}\right)$, OF is outdoor occupancy factor $(0.2), T$ is the exposure time $\left(8760 \mathrm{~h} \mathrm{y}^{-1}\right)$. DL is the duration of life (70 years), RF is a risk factor $\left(\mathrm{Sv}^{-1}\right)$ as fatal cancer risk per Sv [calculate to stochastic effects; ICRP 60 (22)] uses the value of 0.05 for the public (ICRP, 2007).

ADRA values were handled from Table 1 and applied upper formulas. Calculated values for AEDE and also ELCR are shown in Table 2 with average altitudes as regionally.

Table 2: AEDE and ELCR values for Cappadocia.

\begin{tabular}{lcccc}
\hline $\begin{array}{c}\text { Name of measuring } \\
\text { district } \\
\text { [number of m. point] }\end{array}$ & $\begin{array}{c}\text { Av. ADRA } \\
\text { [nGy h-1 }\end{array}$ & $\begin{array}{c}\text { Av. AEDE } \\
\text { [NSv] }\end{array}$ & $\begin{array}{c}\text { Av. ELCR } \\
\text { [(x10-4)] }\end{array}$ & $\begin{array}{c}\text { Av.Altitude } \\
\text { (meter) }\end{array}$ \\
\hline Ihlara Valley [1] & 192.06 & 235.47 & 8.24 & 1180 \\
Derinkuyu [2] & 161.51 & 198.01 & 6.93 & 1350 \\
Uçhisar [3] & 186.24 & 228.33 & 7.99 & 1316 \\
Paşabağları [1] & 192.06 & 235.47 & 8.24 & 1020 \\
Çavuşin [1] & 183.33 & 224.76 & 7.87 & 1050 \\
Göreme [11] & 177.78 & 217.96 & 7.63 & 1116 \\
Cappadocia- central [17] & 180.10 & 220.80 & 7.73 & 1209 \\
Avanos [4] & 166.74 & 204.42 & 7.16 & 945 \\
Ürgüp [3] & 168.78 & 206.92 & 7.24 & 1143 \\
Ortahisar [1] & 192.06 & 235.47 & 8.24 & 1070 \\
Hacıbektaş [1] & 209.52 & 256.87 & 8.99 & 1300 \\
Nevşehir [45] & $\mathbf{1 7 8 . 6 9}$ & $\mathbf{2 1 9 . 0 7}$ & $\mathbf{7 . 6 7}$ & 1162 \\
\hline
\end{tabular}

The frequency distribution of annual gamma doses is shown in the figure below (4.a.) by the related linear fitting curve and its $\mathrm{R}^{2}$ equation. Another graphic (figure 4.b) shows the ELCR values with a logarithmic curve and its $\mathrm{R}^{2}$ equation. 


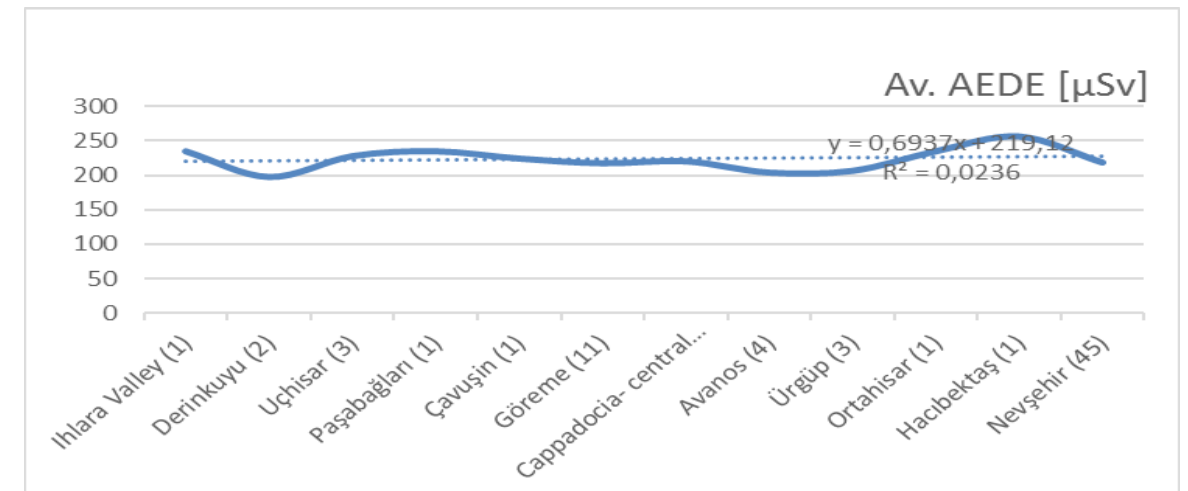

Figure 4.a.: Frequency Distribution of AEDE for Cappadocia (Nevşehir) district.

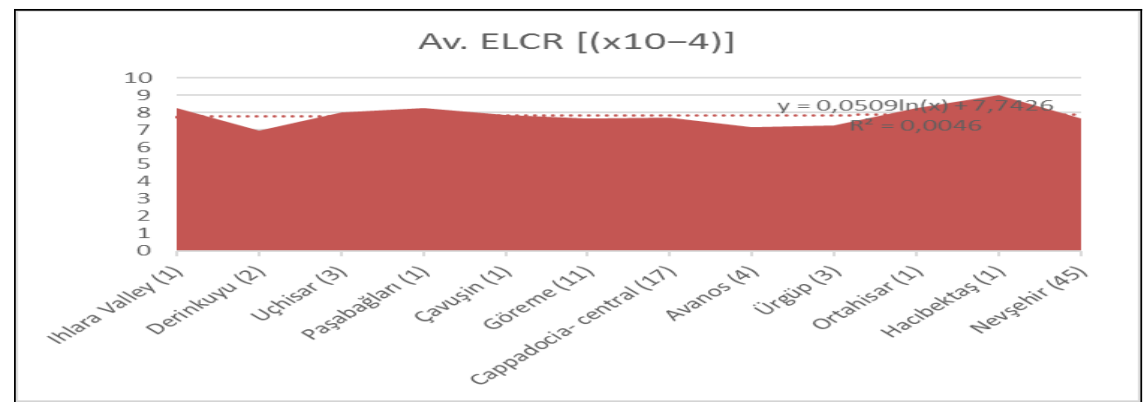

Figure 4.b.: Frequency Distribution of ELCR for Cappadocia (Nevşehir) district.

\section{Statistics}

\section{Standard deviations}

Using the group data such as AEDE and ELCR values of districts (Table 2), it is easy to calculate standard deviations. The standard deviation of AEDE is 10.31 and for ELCR is 0.36 . The deviation rate is not as low as $4.7 \%$ for both AEDE and ELCR values. annual critical values are 219.07 $\pm 10.31 \mu S v$ and $7.67 \pm 0.36\left(\times 10^{\wedge}-4\right)$. Related bar charts are shown in Figure 5.

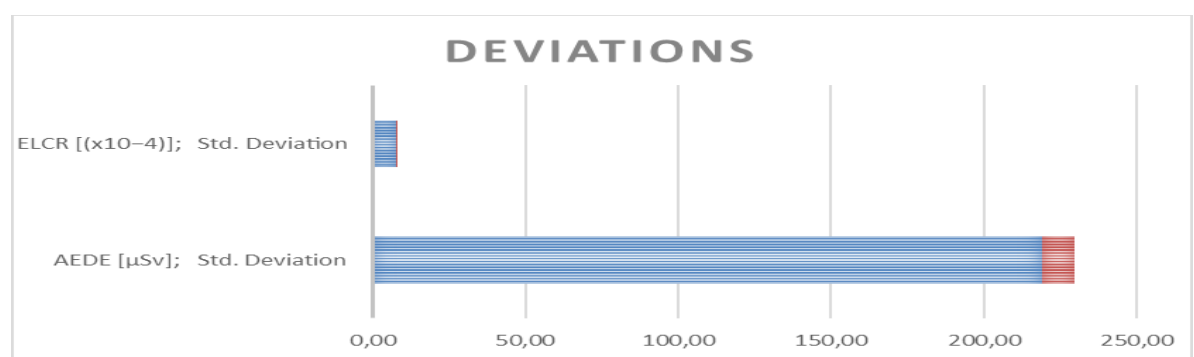

Figure 5: Bar chart for both AEDE and ELCR values and their deviations.

\section{Comparison with literature}

The data in Table 4 pertain to the Figure 6 distribution of Excess Life Time Cancer Risk corresponding to the Annual Effective Dose Equivalent.

Table 4: Comparison for AEDE and ELCR values regarding gamma dose rates.

\begin{tabular}{lccc}
$\begin{array}{c}\text { (ref no), Region, } \\
\text { [nm of samplings] }\end{array}$ & $\begin{array}{c}\text { (AEDE) }[\boldsymbol{\mu S v}], \\
\text { average }\end{array}$ & $\begin{array}{c}\text { ELCR } \\
{\left[\left(\mathbf{x 1 0} \mathbf{1 0}^{-4}\right)\right],} \\
\text { average }\end{array}$ & Reference \\
\hline (02) Hatay [39] & $\begin{array}{c}7.50 \text { (only } \\
\text { alpha) }\end{array}$ & 0.26 & $(2)$ \\
(03) Adana & 82.00 & 2.87 & $(3)$ \\
(04) Ankara [341] & 71.83 & 2.69 & $(4)$ \\
(05) Artvin [204] & 214.50 & 7.50 & (5)
\end{tabular}




\begin{tabular}{lccc} 
(06) Balıkesir [92] & 156.30 & 6.30 & $(6)$ \\
(07) Bolu [74] & 27.23 & 0.95 & $(7)$ \\
(08) Çanakkale [379] & 81.40 & 2.85 & $(8)$ \\
(09) Edirne [14] & 47.30 & 1.66 & $(9)$ \\
Kocaeli [35] & 29.31 & 1.02 & $(\mathrm{np})$ \\
Hatay [215] & 63.93 & 2.24 & $(\mathrm{np})$ \\
(10) IDA [75] & 198.66 & 6.95 & $(10)$ \\
(11) İstanbul [105] & 79.72 & 2.79 & $(11)$ \\
(12) Kastamonu [60] & 58.88 & 2.06 & $(12)$ \\
(13) Şanlıurfa & 74.70 & 2.62 & $(13)$ \\
(14) Van & 142.59 & 4.99 & $(14)$ \\
This work [45] & 219.07 & 7.67 & $(\mathrm{tw})$ \\
(23) Nevşehir [RESA] & 306.50 & 10.73 & $(23)$ \\
(1) World & 73.60 & 2.58 & $(1)$ \\
(15) R. D. J.- Brazil & 90.00 & 3.15 & $(15)$ \\
(16) Ramsar- IRAN & 105.00 & 3.68 & $(16)$ \\
(17) Canary I- Spain & 91.95 & 3.22 & $(17)$ \\
\hline
\end{tabular}

(np): Not published yet. (tw): This work.

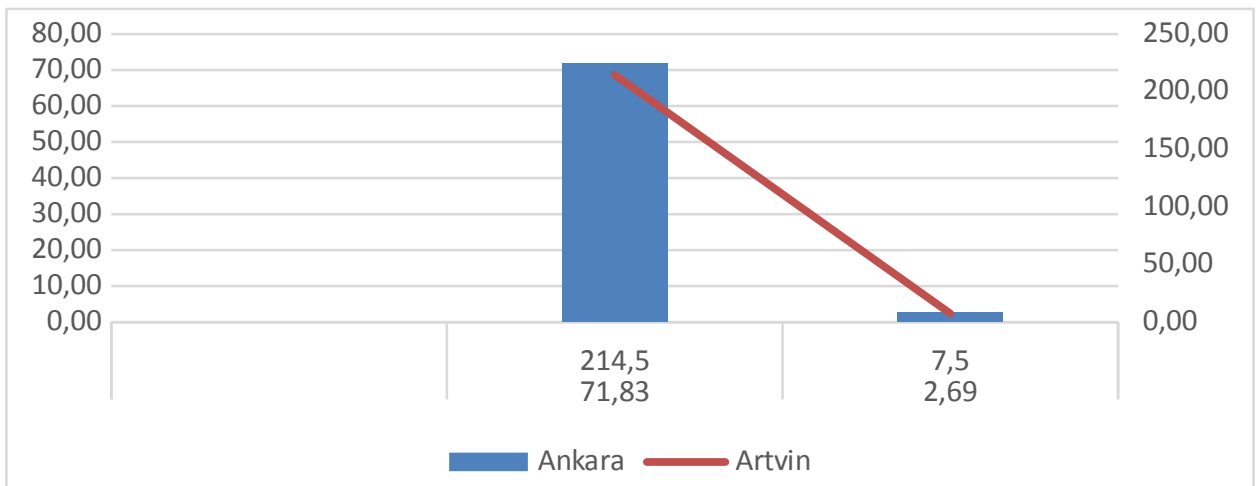

Figure 6: Graphical distribution of AEDE and ELCR [ $\left.\mu \mathrm{Sv} ; \times 10^{-4}\right]$.

\section{Comparison to RESA}

TAEK, the Turkish Atomic Energy Agency, periodically measures the natural radiation in the air by RESA (23) system, consisting of a Geiger detector and reader. Due to this system's locations, there is one measuring point referenced as the central county of Nevşehir province. Below pictures are referred the RESA system in Figure 7.
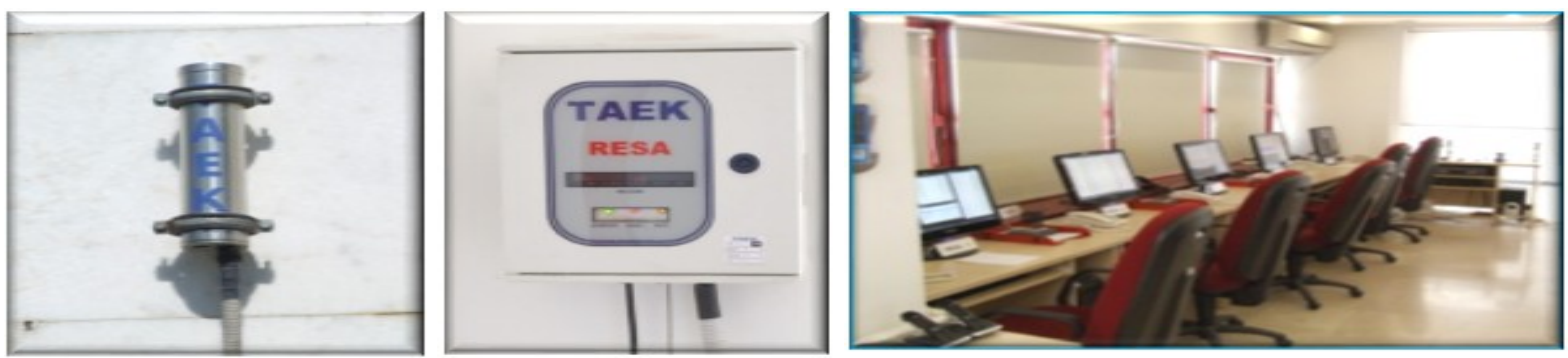

Figure 7: RESA; detector- counter and control center, TAEK (23).

RESA's online value was $175 \mathrm{nSv} \mathrm{h}^{\wedge}-1$, which corresponds to $250 \mathrm{nGy} \mathrm{h}^{-1}$. This dose rate indicates to AEDE value of $306.50(\mu S v)$ and ELCR value as $8.75\left(\times 10^{-4}\right)$. The average of our measurements is $178.69 \mathrm{nGy} \mathrm{h}^{-1}$. Due to our measurements, the minimum rate was 107.38 , and the maximum rate 
was $392.85 \mathrm{nGyh}^{-1}$. There are a few possible reasons due to this difference. There are a few possible reasons for this difference. One of them is that our measurements are not for only one fixed point on the RESA system. Another reason could be the measurement times. Our measurements are not conducted periodically as well as RESA's. Annual doses and cancer risks were compared by the below figure, too.

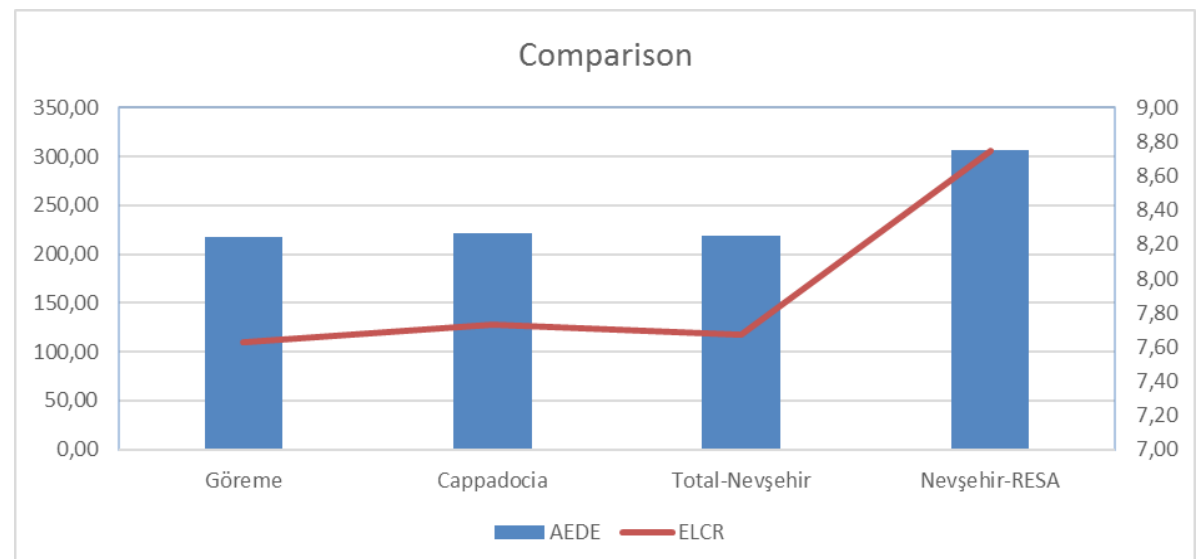

Figure 8: Horizontal Bar chart and line graphic [AEDE in $\mu S v$; ELCR, $\times 10^{-4}$ ]

\section{CONCLUSION}

Due to the measurement results, minimum, maximum, and average dose rates in Cappadocia are 107.38, 392.85, and $180.10 \mathrm{nGy} / \mathrm{h}$, respectively. For the other touristic destinations, namely Avanos and Ürgüp, average dose rates are so close to each other as 166.74 to $168.78 \mathrm{nGy} / \mathrm{h}$, respectively. For Hacıbektaş county, in which the minimum population of Nevşehir lives, the dose rate is $209.52 \mathrm{nGy} / \mathrm{h}$. The average dose rate of Nevşehir is $178.69 \mathrm{nGy} / \mathrm{h}$, and this rate refers to $219.07 \mu \mathrm{Sv}$ as the annual dose. It also refers to $7.67\left(\times 10^{-4}\right)$ as a cancer risk. These values are a little higher than Artvin's values. They also refer to values three times higher than the world's references. Nevşehir is a well known tourist county without sea-sand-sun trio, so gamma-radiation levels are important for visitors as well. Nevşehir is in the middle of Anatolia, especially the north-south axis. Existing nuclear power reactor buildings in Mersin are less than $300 \mathrm{~km}$ away, and it is important to get setting parameters to compare after a possible radioactive fallout. The present study findings' serve as a reference for future studies.

\section{REFERENCES}

1. UNSCEAR. Report of the United Nations scientific committee on the effects of atomic radiation, sources, effects, and risks of ionizing radiation [Internet]. 2008 [cited 2022 Feb 14]. Available from: https://www.unscear.org

2. Turgay ME, Yazici AN, Taskin H, Kam E, Karahan G. Assessment of gross $a$ and $\beta$ radioactivity for drinking water in Hatay province, Turkey. Desalination and Water Treatment. 2016 Mar 2;57(11):4960-5.
3. Değerlier M. Annual Effective Dose of Natural Environmental Radioactivity Measurements for Adana region [PhD Thesis]. [Adana]: Çukurova University; 2007.

4. Turgay ME, Yazici AN, Taskin H, Kam E, Karahan G. Assessment of gross $a$ and $\beta$ radioactivity for drinking water in Hatay province, Turkey. Desalination and Water Treatment. 2016 Mar 2;57(11):4960-5.

5. Kobya $Y$, Taşkın H, Yeşilkanat CM, Çevik U. Evaluation of Outdoor Gamma Dose Rate and Cancer Risk in Artvin Province, Turkey. Human and Ecological Risk Assessment: An International Journal. 2015 Nov 17;21(8):2077-85.

6. Kapdan E, Varinlioglu A, Karahan G. Outdoor radioactivity and health risks in Balikesir, northwestern Turkey. Radiation Protection Dosimetry. 2012 Feb 1;148(3):301-9.

7. Ateş NZ, Bayrak K, Turgay ME, Kam E. Evaluation of Excess Lifetime Cancer Risk Caused by External Exposure due to Natural Radioactivity in Bolu, Turkey. Sigma Journal of Engineering and Natural Sciences. 2020;38(2):945-54.

8. Kam E, Bozkurt A, Ilgar R. A study of background radioactivity level for Canakkale, Turkey. Environ Monit Assess. 2010 Sep;168(1-4):685-90.

9. Yümün ZÜ, Bayrak K, Aksoy H, Ayseli U. A Study of Background Radioactivity Level for Edirne, Turkey. Journal of Engineering Technology and Applied Sciences. 2018 Aug 30;3(2):135-9.

10. Turgay ME. Cancer Risk Determination for IDA villages by using Annual Gamma Doses in Air, around Edremit\&Ayvacık Districts; 
Balıkesir\&Çanakkale, TURKEY. European Journal of Science and Technology. 2019 Mar 31;433-9.

11. Karahan G, Bayulken A. Assessment of gamma dose rates around Istanbul (Turkey). Journal of Environmental Radioactivity. 2000 Jan;47(2):21321.

12. Kam E, Bozkurt A. Environmental radioactivity measurements in Kastamonu region of northern Turkey. Applied Radiation and Isotopes. 2007 Apr;65(4):440-4.

13. Bozkurt A, Yorulmaz N, Kam E, Karahan G, Osmanlioglu AE. Assessment of environmental radioactivity for Sanliurfa region of southeastern Turkey. Radiation Measurements. 2007 Sep;42(8):1387-91.

14. Akan Z, Baskurt B, Asliyuksek H, Kam E, Yilmaz $A$, Yuksel MB, et al. Environmental Radioactivity and High Incidence Rates of Stomach and Esophagus Cancer in the Van Lake Region: A Causal Relationship? Asian Pacific Journal of Cancer Prevention. 2014 Jan 15;15(1):375-80.

15. Licínio MV, Freitas AC, Evangelista $H$, CostaGonçalves A, Miranda M, Alencar AS. A high spatial resolution outdoor dose rate map of the Rio de Janeiro city, Brasil, risk assessment and urbanization effects. Journal of Environmental Radioactivity. 2013 Dec;126:32-9.

16. Ghiassi-nejad M, Mortazavi SMJ, Cameron JR, Niroomand-rad A, Karam PA. Very High Background Radiation Areas Of Ramsar, Iran: Preliminary Biological Studies. Health Physics [Internet]. 2002;82(1). $\leq$ URL $>$.

17. Arnedo MA, Rubiano JG, Alonso $H$, Tejera $A$, González A, González J, et al. Mapping natural radioactivity of soils in the eastern Canary Islands. Journal of Environmental Radioactivity. 2017 Jan;166:242-58.

18. Eberline. Eberline esp2 technical manual [Internet]. $\leq$ URL $>$.

19. Governorship of Nevşehir. 2020.

20. Kapadokya Rehberli Turlar. Kapadokya Rehberli Turlar [Internet]. [cited 2022 Feb 14]. $\leq$ URL $>$.

21. Paintmaps.com. COLOR MAPs with STATISTICAL DATA. [Internet]. 2014 [cited 2022 Feb 14]. $<U R L>$.

22. ICRP. Publication 103 recommendations of the ICRP: annals of the ICRP volume $37 / 2-4$. Pergamon Press; 2007.

23. TAEK. Radiation Measurement Systems (RESA). 
